\title{
Ineffectiveness in natural resource management in modern society: Geoparks proposed as possible tools for increasing awareness in the short to medium term
}

\author{
Geologic Park of Aliaga, Calle San Antonio s/n. Aliaga 44150, Teruel, Spain, *Corresponding author, E-mail: jumidosiv@gmail.com
}

(Received: July 20, 2015; Revised accepted: February 1, 2016)

http://dx.doi.org/10.18814/epiiugs/2017/v40i1/017008

Despite the fact that Earth Sciences can contribute greatly to the understanding of the socio economic system in our communities, the reduction of Earth Science education in curricula and ineffective territorial assessment is now a fact of life in post-industrial society. The objectives of the article are: (a) to show the implications of the decrease in environmental knowledge of the population, and (b) to propose Geoparks as a possible tool in the short to medium term to interact to improve natural resource management. Research conducted over the last five years in the Geologic Park of Aliaga shows that the population has a poor knowledge of environmental issues and of natural resource assessment and exploitation. The results are more significant if we consider the differences between people from rural areas and cities. This fact is more important in the education and development of potential future managers (students at present in school) who currently cannot properly identify geological resources and do understand criteria for their evaluation. I propose Geoparks to try to redress the current lack of geological and environmental knowledge.

\section{Introduction}

"Today's human beings use and abuse Nature as if they were the last tenant of this unfortunate planet, as if there was no future after them" (Delibes, 1990).

Geosciences have a great capacity to help societal understanding of the relevance of the Earth's natural and physical system in light of society's economic activities, and at the same time, to support development of critical attitudes on the part of populations (Domingo and Sequeiros, 1998) in order to avoid or minimize unintended consequences of 'unsustainable' human behavior.

Earth Sciences knowledge is well connected with rural culture because rural work joins society and nature (Brunhes, 1947) with a sustainable use of nature through understanding of natural cycles and dynamics (Cloke, 1997). Nevertheless, the reduction of rural popula- tions in Spain during the 1960s has led to a socio-cultural change with urban culture rising as rural culture decreases (Paniagua, 2011). Thus, more than fifty years later, the first generation without direct rural environmental experience is forming most of the modern population.

In this context a scientific reductionist approach is happening (Gallagher and Appenzeller, 1999). Actual reduction takes place at two levels: (a) the education level and (b) the territorial assessment level. At the educational level, the amount of Earth Sciences is being progressively reduced in almost all curricula. At the territorial assessment level, a simplification process is occurring, that can be detected in scientific terms like "geoconservation" and "geodiversity". A restrictive concept of geodiversity has dominated during the last years where geodiversity has been identified with "geological diversity" (Serrano and Ruiz Flaño, 2007). A more complete approach to the term geodiversity should include bedrock, landforms and soils, which together form the essential and integral basis of the broader ecological system (Sharples, 2002; Gray, 2004). Due to the reduction in geoscience curricula and this territorial management bias as well as through a simplification of definitions of natural areas, several authors, associations and collectives have pointed to the need for more teaching of geosciences in secondary schools (Fermeli et al., 2011), and the necessity to include geology in a holistic vision of territory for the whole of society; see also the report called "Geology for a new Earth culture" (Villaroya et al., 2012). However, irreparable effects with respect to the sustainability of Spanish territories are being overlooked, and they will occur even more often if we do not act immediately in order to solve this problem that has developed over decades, but is now in a critical state.

For all of the above mentioned reasons, in this article I have two objectives: to show the implications of the decrease in environmental knowledge of the population, and to propose Geoparks as a possible tool in the short to medium term to deal with the problem of ineffective natural resource management in modern society

\section{Methods}

The methodology

The research methodology used to undertake this study is based on 
Table 1. Sample characterization

\begin{tabular}{|c|c|c|c|}
\hline $\begin{array}{c}\text { People from samples } \\
\text { A and B }\end{array}$ & Origin & Age (year old) & $\mathrm{n}$ \\
\hline \multirow{3}{*}{ Group A. Children } & \multirow{2}{*}{ Rural area } & $12-13$ & 31 \\
\cline { 3 - 4 } & & $14-15$ & 31 \\
\cline { 3 - 4 } & \multirow{2}{*}{ City } & $12-13$ & 31 \\
\cline { 3 - 4 } Group B. Adults & \multirow{2}{*}{ Rural area } & $14-15$ & 31 \\
\cline { 3 - 4 } & \multirow{2}{*}{ City } & $<35$ & 25 \\
\cline { 3 - 4 } & & $>35$ & 25 \\
\cline { 3 - 4 } & & & 25 \\
\hline
\end{tabular}

qualitative semi-structural interviews conducted over five years (20082013) following the methodological approach proposed by Valles (2002).They covered representative sectors of the population: school students, urban and rural people (Table 1).

We chose the qualitative personal interview because this methodology is one of the most useful to obtain information in a complex context (Vargas, 2012). Likewise, this kind of interview is an effective way to get information about understanding of the importance of natural resources and the potential environmental consequences of extracting them. This is the point of view necessary for this research.

\section{The site}

This study has been carried out in the Geologic Park of Aliaga. This Park was created in 1993 in Spain and is a pioneer in the development of parks through focusing on exceptional national and international geoheritage. A "Geologic Park" is not a new category of protected area, but is a new concept related to geoheritage, which highlights, as its main objectives, conservation and valuation of the geological, natural and cultural resources of a specific area (Escorihuela, 2011). At

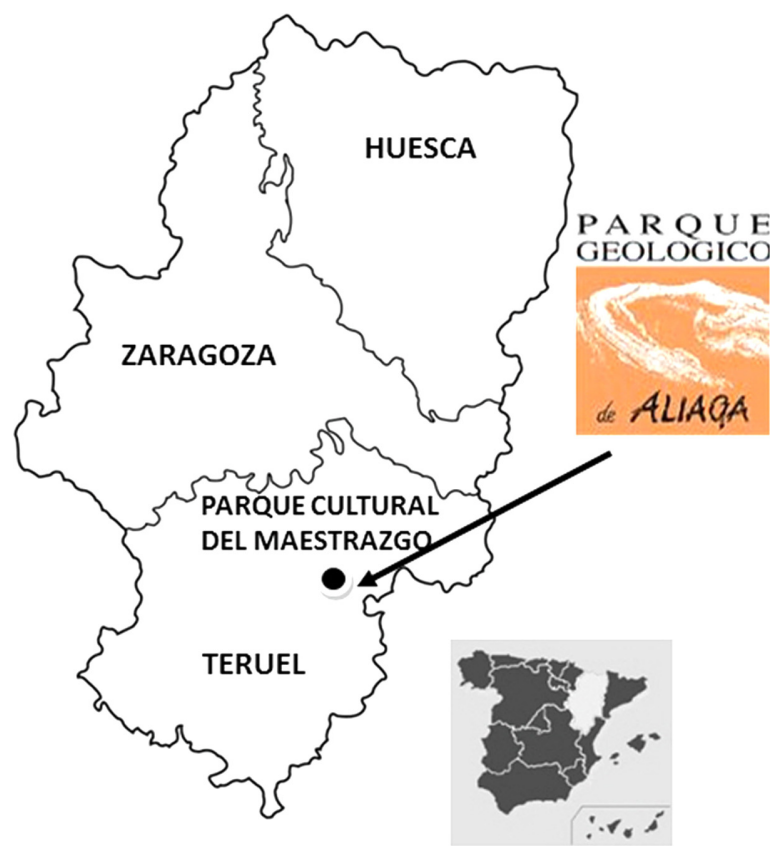

Figure 1. Location of the Geologic Park of Aliaga and Maestrazgo Geopark (Also called Parque Cultural de Maestrazgo) within Spain. present, the Geologic Park of Aliaga (PGA) is situated within the Maestrazgo Geopark (Fig. 1).

In 2006, when a visitors' center was established, a local company called Jumidosiv was appointed to manage geotourism within the Park. Education in geosciences was addressed at different levels depending on the type of geotourists and their educational levels (Fig. 4). Activities include:

Guided tours for general geotourists: visitors to PGA are composed of groups of families and friends, geologists, academics involved in environmental themes, land managers and local agents, and

A special program of guided tours and courses for primary and secondary students.

The data presented in this paper were collected over the last five years from samples of this varied population, based on people of different ages, origins, jobs and educational levels.

\section{Characteristics of the selected groupings}

Our research sampled two different groups in order to obtain appropriate results for the study: Group A, composed of children, and Group B, composed of adults.

Group A was comprised of 124 children. Of these, 62 were in the first level of secondary education (12-13 years old), and 62 were in higher levels (14-15 year old). Fifty percent of each level comprised children that lived in rural areas and 50\% children that lived in cities, as shown in Table 1.

The research protocol was agreed and approved by the teachers of each of the schools involved in this study. Furthermore, no video or audio recording was made in order to protect the anonymity of participants in the research.

Group B was comprised of 100 adults of whom 50 were younger people $(<35$ year old), and 50 were older $(>35$ year old). Table 1 shows the percentages of people from cities and rural areas respectively.

The results obtained from people living in urban and rural areas differ not only in population size and morphology, but also in a different concentration of various activities, people and cultures in one place (Pacione, 2001).

\section{Procedure and description of interviews}

To improve interviews, this methodology included several complementary qualitative techniques such as observation, informal conversation, and indirect documentary sources like national and regional journals, local bulletins and programs of students' parents associations. It is important to highlight that all the interviews were conducted by the author to avoid differences in the evaluation of indices.

As Valles (2002) suggests we planned a thematic analysis in the interviews, grouping the material around the most relevant subjects. In order to identify in an analytical and quantitative way the differences between environmental education and information, we established two indices: the environmental knowledge index (EK), and the environmental and territorial politics knowledge index (ETPK). Table 2 shows these indices and the related variables evaluated in each index.

The characteristics and procedures followed regarding these indices are presented below. 
Table 2. Index and items evaluated in interviews

\begin{tabular}{|c|c|}
\hline \multicolumn{2}{|l|}{ Indexes Variables } \\
\hline \multirow{6}{*}{$\begin{array}{l}\text { EK environmental knowledge index } \\
E K=\frac{e * 16.6}{10}+\frac{r f * 16.6}{10}+\frac{p * 16.6}{10}+\frac{p h c * 16.6}{10}+\frac{a h c * 16.6}{10}+\frac{w c * 16.6}{10}\end{array}$} & erosion (e) \\
\hline & rock formation (rf) \\
\hline & pollution $(\mathrm{p})$ \\
\hline & Plant's habitat conservation (phc) \\
\hline & Animal's habitat conservation (ahc) \\
\hline & water cycle $(\mathrm{wc})$ \\
\hline \multirow{3}{*}{$\begin{array}{l}\text { ETPK environmental and territorial politics knowledge index } \\
\text { ETPK }=\frac{n r * 25}{10}+\frac{t p * 25}{10}+\frac{e p * 25}{10}+\frac{r l m * 25}{10}\end{array}$} & natural resources (nr) \\
\hline & territorial politics (tp) \\
\hline & projects concerning the extraction of natural resources (ep) \\
\hline $\begin{array}{l}\text { Education index } \\
E i=\frac{n r * 25}{10}+\frac{r l m * 25}{10} \\
\text { Information index } \\
l i=\frac{t p * 25}{10}+\frac{e p * 25}{10}\end{array}$ & repercussions of the land management (rlm) \\
\hline
\end{tabular}

Note: Because of a more intuitive evaluation, every variable was scored over 10 points. Different weights in the formula allow an optimal treatment of results integrated in the indices.

\section{Items evaluated in the interviews}

\section{The environmental knowledge index (EK)}

This index was used for children, by means of individual interviews and by asking different questions. Their environmental knowledge was evaluated by selecting aspects like: erosion, rock formation, pollution, plant and animal habitat conservation, and the water cycle. Finally all subjects were integrated in the index as shown in Table 2.

\section{The environmental and territorial politics knowledge index (EPTK)}

The environmental and territorial politics knowledge index developed to conduct this research is founded upon a similar methodology as the EK index. The EPTK was appropriate for adults, in the same way as the EK index was used for children. Nevertheless, the subjects evaluated in this index were more complex and it took more time to measure them in a correct way. The ETPK index included knowledge about the following concepts: natural resources, territorial politics, projects concerning the extraction of natural resources, and repercussions for land management (Table 2).

\section{The education-information indices in rural areas}

Finally, to study the differences between knowledge of natural resources and the information of adults from rural areas, other indices were analyzed: Education index (Ei) and Information index (Ii). These indices were secured by adding the sum of the variables related with environmental knowledge (natural resources and repercussions for land management) $-\mathrm{Ei}-$, and the sum of the variables related to political information (territorial politics and projects concerning the extraction of natural resources) $-\mathrm{Ii}-$. Table 2 shows these indices.

\section{Data analysis}

Parametric bifactorial ANOVAs were used to analyze the differences in the EK index between ages and origin of children. The same statistical tool was used to explore the differences in the ETPK index between ages and origin of adults. Post hoc Tukey tests were used to determine differences on both EK and ETPK indexes between groups.

In order to identify the differences in the variables related to education (Ei) and information (Ii) of adults of rural areas, non-parametric Kruskall-Wallis ANOVA test was used.

Parametric ANOVA and non-parametric Kruskall-Wallis tests determine whether the differences between the samples are simply due to random error (sampling errors), or whether there are systematic treatment effects that cause the mean in one group to differ from the mean in another. Both methods are based on comparing the variance (or variation) between the data samples to variation within each particular sample. If the variation between is much larger than the variation within, the means of different samples will not be equal. If the variations between and within are approximately the same size, then there will be no significant difference between sample means.

All statistical calculations have been carried out with the STATISTICA 6.0 package (Statsoft 2001).

\section{Results}

The results of the study are presented as follows: (1) first of all the data obtained from testing the environmental knowledge of the children is introduced; (2) followed by the figures and tables related to the analysis of the environmental and territorial politics knowledge of adults; (3) and, finally, the study of differences between information and education of adults from rural areas is shown.

The evident differences between Ei and Ii will have implications for land management and the sustainability of rural areas, as presented in the discussion section of this article.

\section{Environmental knowledge in children (EK index)}

There were differences in the EK index between children from rural areas and children from cities (Fig. 2), with significant effects of ori- 


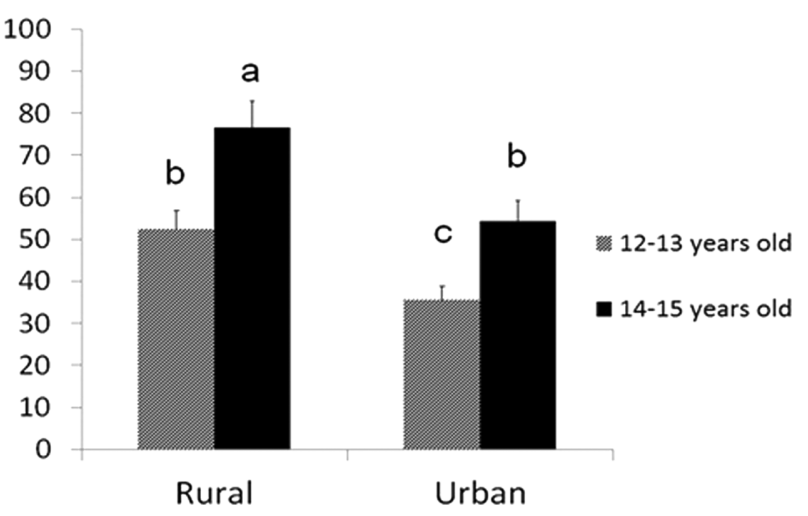

Figure 2. Environmental knowledge index (error bars indicate the standard deviation) of children 12-15 years old from rural areas and cities. Different letters indicate significant differences with the post hoc Tukey tests $(p<0.01)$.

gin $\left(\mathrm{F}_{1,124}=539.8, \mathrm{p}<0.01\right)$, and age $\left(\mathrm{F}_{1,124}=658.3 ; \mathrm{p}<0.01\right)$. A higher environmental knowledge was found with children of $14-15$ years old from rural areas $(76.51 \pm 6.29$, mean $\pm \mathrm{SD})$ than those from cities and also of $13-14$ years old $(35.59 \pm 3.14$, mean \pm SD).

The environmental and territorial politics knowledge of adults (ETPK index)

ETPK index of the adults from rural areas and cities showed significant effects of origin $\left(F_{1,100}=351.1 ; p<0.01\right)$ and age $\left(F_{1,100}=86.4 ; p\right.$ $<0.01)$. The ETPK index was higher for adults $>35$ years old from rural areas $(67.50 \pm 4.69$, mean $\pm \mathrm{SD})$, and the ETPK index was lower for adults $<35$ years old from cities $(37.50 \pm 5.66$, mean \pm SD) (Fig. 3).

Differences between environmental education and understanding of land politics and natural resource projects are obvious: Fig. 4 displays the values found in the sample of adults $>35$ years old from rural areas.

It is worth highlighting that the above mentioned significant differences were found between these two categories of environmental knowledge (Kruskal-Wallis test: $\mathrm{H}_{1,100}=61.85, \mathrm{p}<0.01$ ).

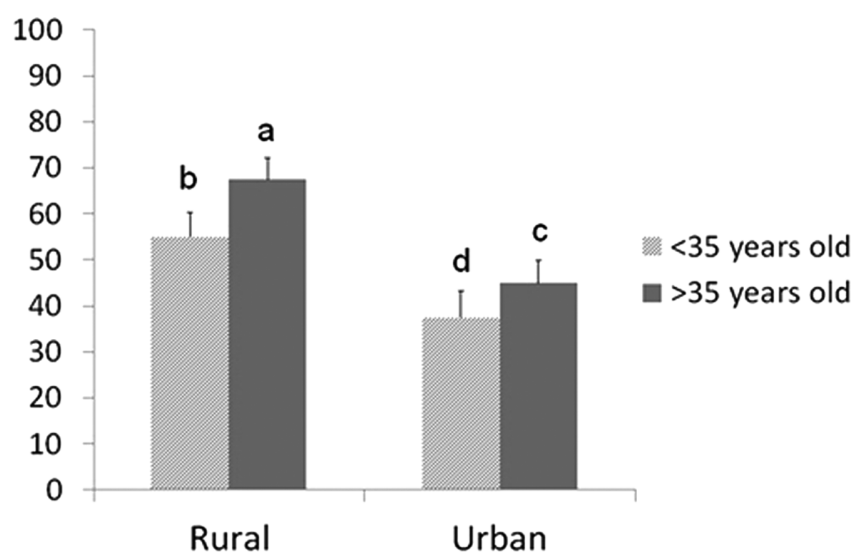

Figure 3. ETPK index (error bars indicate the standard deviation) of adults between $<35$ years old and $>35$ years old from rural areas and cities. Different letters indicate significant differences with the post hoc Tukey tests $(p<0.01)$.

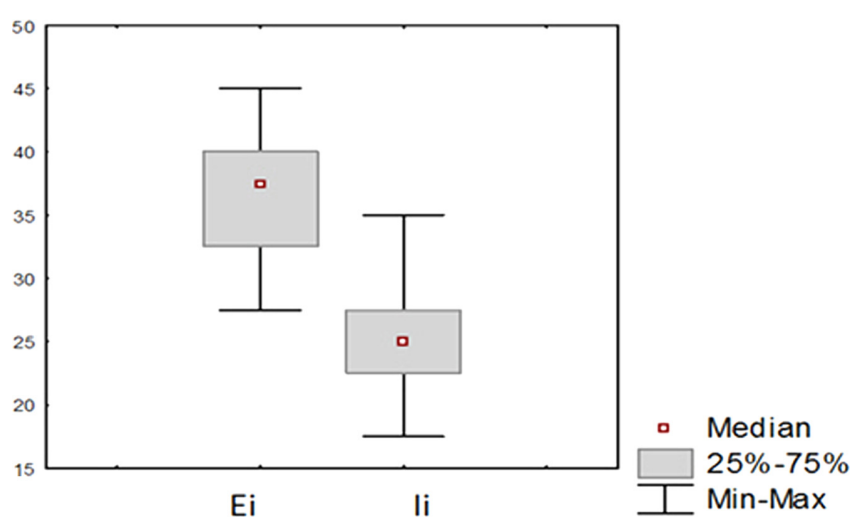

Figure 4. Education-Information indices only for adults $>35$ years old from rural areas.

\section{Discussion}

The discussion of the results will start by addressing the conclusions of the data provided by the environmental knowledge (EK), separated from those of the environmental and territorial politics knowledge index (ETPK). Thereafter, an integrated vision of information collected by both tests will be offered. The closing section of this chapter will cover the implications for future research in Geoparks as a useful tool.

As a result of our research during the past five years in a Geologic park we can affirm that the population - with an average environmental index of $50 \%$ - has a low level of knowledge of the environment and understanding of natural resources and their exploitation (Fig. 5). The results are more significant if we consider the differences between people from rural areas and cities.

On the other hand, with respect to the educational level, primarysecondary teachers have no possibility of teaching geosciences because of the reduction in curricular content. Thus, students in school cannot properly identify geological resources and do not have any understanding of criteria for their evaluation. This fact is confirmed by an average value of the EK index less than 55\%. Also, adults - with and without an higher educational backgrounds - showed no relation to the countryside and little knowledge of natural resources management or the short to medium term repercussions of exploitation. An average

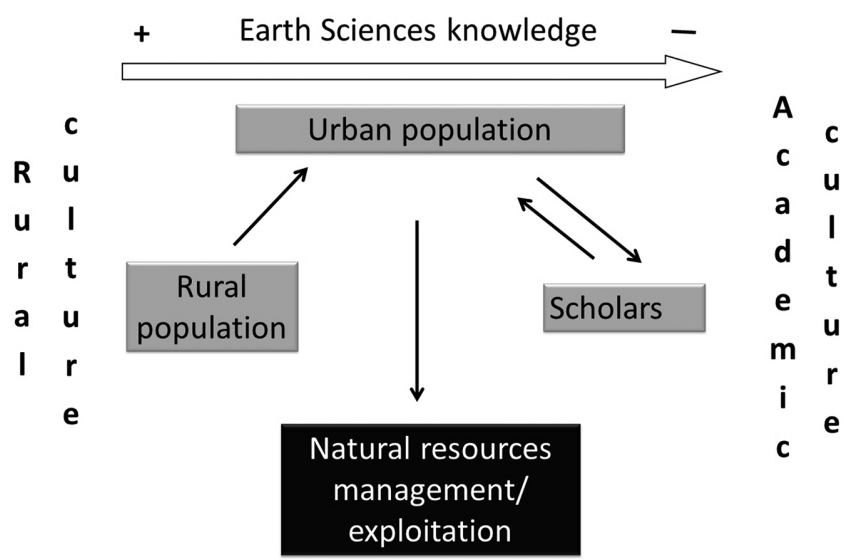

Figure 5. Geosciences knowledge reduction dynamics in different societal groups and their implications for understanding of natural resources and their exploitation. 
value of ETPK index less than $52 \%$ confirms this situation. This lack in knowledge (educational reduction) leads to limited, partial and sometimes useless management measures, and probably leaves the population in general unable to understand or solving complex environmental problems.

Rural populations, which are more connected with nature, showed significant differences in environmental knowledge compared to urban populations (see Fig. 3). Nevertheless, according to Taberner Guasp (2008), little or non-existent political support in rural areas for academic development has resulted, in the fact that urban people are more likely to hold high positions in government bureaus of land management. This is reflected also by the differences between environmental knowledge (Ei) and territorial political information (Ii) (see Fig. 4). Rural-urban patterns are complex and influenced by a wide range of factors (Pahl, 1966). Marginalization of rural populations has contributed to a dualism and a situation of imbalance for decades (Pérez Prado, 1993). Although the modernization paradigm that dominated the past policy is now being replaced by a new rural development paradigm (Van Der Ploeg et al., 2000), a wider social scientific approach should be implemented that could lead to a "cultural turnaround" acknowledging the importance of traditional knowledge of landscapes.

Unfortunately, there are authorities in Spain which lack good rural environment linkages that legislate for resources exploitation, leaving the rural population without sufficient information about projects with potentially negative effects, that might affect them directly. Rural populations - with an environmental education - would have the knowledge and ability for territorial impact assessment.

A Geopark is usually understood to be an area designated for its geological and/or geomorphological (i.e., landscape) interest and in which this heritage is used for sustainable development. It is important not only for geological scientific interest but also for its archeological, ecological and cultural values (European Geoparks Network, 2011). Geoparks work together by means of international networks on a European and global scale. Geoparks appeared for the first time in the 1990s and are united under the Global Geoparks Network and to become UNESCO Global Geoparks in 2015.

The scientific community is promoting the necessity of reintroduction of geoscience education in both formal and informal learning and a new approach based on field activities, fighting against the reduction in Earth Sciences education over decades that threatens the development of our future professionals, and also threatens the understanding of information about resource projects that may seriously impact the environment (Escorihuela, 2015).

Geoparks are already useful and could be even more useful tools to interact in the ineffectiveness in natural resource management in modern society. These geological tools are being developed and assessed in Geoparks (Dowling, 2011; Hose, 2011; Serrano and Trueba, 2011).

\section{Conclusions}

In the Geoparks, geoscience education could be easily combined with geotourism in a natural environment connected with rural culture. This strategy would allow us to reintroduce geological and biological knowledge at various educational levels and in informal education programs. Competent evaluation and research of geotourism projects requires a multidisciplinary approach. It is also obvious that sound geoscience knowledge and field expertise are necessary research attributes. Likewise a knowledge and application of social science, tourism and geographical methodologies is deemed essential (Hose, 2011). At all educational levels, school and university environmental programs should be carried out through field work, involving cooperation with the Ministry of Education and Science. Nevertheless Geoparks are also informal spaces for education and should be used as consider as relevant sites in which to complement and disseminate understanding to help to convert abstract concepts in favour of concrete understanding. Also, Geoparks networks would be appropriate to promote international exchange programs to accelerate knowledge acquisition with a broader approach. At the informal education level, through geotourism, populations could be informed not only about geologic concepts but also about the politics of resource assessment and exploitation. In this way, society gain the necessary geological basis for recovering the socio-environmental equilibrium and promote sustainability.

To conclude, these results imply that societal sustainability would be likely to affect countries with a similar post-industrial trajectories for at least half a century. Measures to improve environmental knowledge would give Geoparks a new and vital role.

\section{Acknowledgements}

The author wishes to thank S. López and Dr. Palacios for assistance in translating this paper. The author is indebted to Dr. Wolfgang Eder and Godfrey Nowlan who undertook a helpful revision of the paper and Dr. Vasconcelos for a final helpful revision. Special thanks should be given to Dr. Fareeduddin.

\section{References}

Brunhes, J., 1947, La geographie humaine: Presses Universitaires de France, Paris $393 \mathrm{p}$.

Cloke, P., 1997, Country backwater to virtual village? Rural studies and "the cultural turn": Journal of Rural Studies, v.13, no.4, pp. 367-375.

Delibes, M., 1990, Un Mundo que Agoniza: Esplugues de Llobregat, Barcelona, $168 \mathrm{p}$.

Domingo, T.M., and Sequeiros, L., 1998, La extinción de la Geología en España: alerta roja: Enseñanza de las Ciencias de la Tierra, v.6, no.3, pp. 206-210.

Dowling, R.K., 2011, Geotourism's global growth: Geoheritage, v.3, no.1, pp. 1-13.

Escorihuela, J., 2011, Los recursos geológicos y el desarrollo local desde una perspectiva no depredadora. Aplicación en las manifestaciones sociales de la geología: el geoturismo y los parques geológicos, in Fernández Martínez, E., and Castaño de Luis, R., eds., Avances y retos en la conservación del patrimonio geológico en España. Actas de la IX reunión nacional de la comisión de patrimonio geológico: León, Univ. de León, pp. 109-113.

Escorihuela, J., 2015, El método de geodidáctica desarrollado en el Parque Geológico de Aliaga (Teruel): incorporación de edades más tempranas en la enseñanza de las ciencias de la tierra. Libro de resúmenes y programa de La XXI Bienal de la Real Sociedad Española de Historia Natural: Burgos, $117 \mathrm{p}$.

European Geoparks Network, 2013, What is a Geopark: http://www.europeangeoparks.org/?page_id $=165$

Fermeli G., Meléndez, G., Calonge, A., Dermitzakis, M., Steininger, F., 
Koutsouveli, A., Neto de Carvalho, C., Rodrigues, J., D'Arpa, C., and Di Patti, C., 2011, Geoschools: innovative teaching of geosciences in secondary schools and raising awareness on geoheritage in the society, in Fernández Martínez, E., and Castaño de Luis, R., eds., Avances y retos en la conservación del patrimonio geológico en España. Actas de la IX reunión nacional de la comisión de patrimonio geológico: Leon, Univ. de Leon, pp. 120-124.

Gallagher, R., and Appenzeller, T., 1999, Beyond reductionism: Science, v.284, no. 5411, pp.79-80.

Gray, M., 2004, Geodiversity, valuing and conserving abiotic nature: John Wiley \& Sons, Chichester, $434 \mathrm{p}$.

Hose, T.A., 2012, Editorial: geotourism and geoconservation: Geoheritage, v.4, pp. 1-5.

Pacione, M., 2001, Urban geography: a global perspective: Routledge, London, $663 \mathrm{p}$.

Pahl, R.E., 1966, The rural-urban continuum: Sociologia Ruralis, v.6, no.3, pp. 299-239.

Paniagua, A., 2011, Despoblación, identidades y escenarios socioculturales. Algunas lecciones para el conocimiento geográfico: Revista Geográfica de América Central, v.2, no.47E, pp. 1-14.

Pérez Prado, L.N., 1993, Lo rural y la ruralidad: algunas reflexiones teóricometodológicas: Estudios de Historia y Sociedad, v.14, no.54, pp. 5-20.

Serrano-Cañadas, E., and Ruiz-Flaño, P., 2007, Geodiversidad: concepto, evaluación y aplicación territorial. EL caso de Tiermes Caracena (Soria): Boletín de la A.G.E., v.45, pp. 79-98.
Serrano, E., and González Trueba, J.J., 2011, Environmental education and landscape leisure. Geotourist map and geomorphosites in the Picos de Europa national park: Geojournal of Turism and Geosites, v.2, no.8, pp. 295-308.

Sharples, C., 2002, Concepts and principles of geoconservation: http:// www.dpiw.tas.gov.au/inter.nsf/Attachments/SJON-57W3YM/\$FILE/ geoconservation.pdf.

Taberner Guasp, J., 2008, Sociología y educación: el sistema educativo en sociedades modernas. Funciones cambios y conflictos: Tecnos, Madrid, $361 \mathrm{p}$.

Valles, M., 2002, Entrevistas cualitativas, vol. 32 of Colección Cuadernos Metodológicos: Centro de Investigaciones Sociológicas, Madrid, $195 \mathrm{p}$.

Van Der Ploeg, J.D., Renting, H., Brunori, G., Knickel, K., Mannion, J., Marsden, T., de Roest, K., Sevilla-Guzmán, E., and Ventura, F., 2000, Rural development: from practices and policies towards theory: Sociologia Ruralis, v.40, no.4, pp. 391-408.

Vargas, I., 2012, The interview in the qualitative research: trends and challengers: Revista Calidad en la Educación Superior, v.3, no.1, pp. $119-139$.

Villaroya, F., Simón, J.L., Pérez-Cueva, A., Beltrán, F., Escorihuela, J., Inigo, I.A., and Martínez-Gil, F.J., 2012, Geología para una nueva cultura de la Tierra: Enseñanza de las Ciencias de la Tierra, v.20, no.3, pp. 305-307. 